\title{
Analysis of Factors Dimensions of Quality Service and Customer Satisfaction Effect on Housi in Makassar, in South Sulawesi, Indonesia
}

\author{
Muklis Kanto, Patta Rapanna, Heslina \\ Lecturer of High School Economics Makassar Bongaya,
}

\begin{abstract}
Housing and settlement are one of human basic requirements and that is the important factor in increasing their level and status.The increasing of society interest of having a house in urban areas be the main tringger of developer companies appear that compete with service quality. In this case, marketing management be an important think to give attention. The aim of this research is to know that how far thew quality of marketing mix, quality of vicinity, and quality of interaction as service quality dimension which generally perceive by housing customer influenced positively and significantly to the customer satisfaction.This research used sampiling from housing customer in Makassar City in three stratums that are housing customer type A (simpledents by using healthy house), type B (middle house) and type $\mathrm{C}$ (luxurious house). The sampling used randomly and based on stratum (stratified random sampling) the sampiling of this research consisted of 125 respondents by using questionnaire which used likerd scale and the data analysis used AMOS program.The result of the research which used hirerachical opproach in measure the service quality shows that the service quality have positive influential and significant for customer satisfaction, marketing mix have positive influential and significant for customer satisfaction, vicinity have positive influential and does not significant for customer satisfaction.
\end{abstract}

Keyword:- Servce, quality, Customer, Marketing, Satisfaction.

\section{INTRODUCTION}

In the competition, the focus of attention should be directed at the process of the achievement of customer satisfaction. Customer satisfaction should not be considered as a final objective but should be seen as a process of internal fixes to do: for the level of trust to the company can be decreased by the company's behaviour towards customers who are less sympathetic like the arrogance of the company, employee and management behaviour and lack of communication.

It is therefore interesting to researched and examined a few more factors that can affect the satisfaction of residential customers. Residential customers meant is a person (user) who purchased the home by way of credit so that the customers concerned will conduct the interaction at any time by the company's marketers as well as other Parties included in the stake holders of residential services. The factors that will be noticed is price, promotion, service, quality home, comfort and empathy.

Both factors that relate to the quality of the marketing mix as well as the quality of the interaction factor coupled with the quality of the physical environment factors will be examined its effects, correlation ties, as well as the dominant factors which affect customer satisfaction. In addition it will also be examined further customer satisfaction level of our customers on various strata of good housing, type A (simple home healthy), type B (Middle House), and type C (mansion). For it's author raised research topics

Research done is a replication of Parasuraman et.al. (1988) by using samples from the company field of banking services, pest control, laundry and fast food. The instrument used is the instrument in the SERVQUAL, but his analysis is done using a model comparison was made of the instrument. Using analysis tools for better analysis, i.e., confirmatory factor analysis and structural equation modeling, Cronin and Taylor was able to do a test model with good.

The similarities with the author is research done in terms of service quality measurement paradigm which is based on the kenerja quality of service perceived by users of the service and the conceptualization of quality services as invalid constructs multidimensional and Multilevel. The difference is in the underlying dimensions of quality of services, research and study object variables. The variable in this study is more extended compared to the variable that is used by the Dabhoikar et.al. (1996) by adding customer satisfaction as the dependent variable. The difference lies in the number of dimensions, the type of dimension and the underlying quality of subdimensi service.

A. Problem

- How to influence the quality of services towards customer satisfaction.

- How to influence the marketing mix towards customer satisfaction.

B. Research objectives

- Find out and analyze the influence of the quality of services towards customer satisfaction.

- Knowing and analyzing the influence of marketing mix towards customer satisfaction. 


\section{A REVIEW OF THE LITERATURE}

The Sense Of Customer Satisfaction And The Factors That Affect Its Customer Satisfaction According To The Experts

\section{According To The Experts}

According to Kotler and Armstrong (2001:9): consumer satisfaction is the extent to which the assumptions of performance products meet the expectations of buyers. When the performance of the product is lower than the expectations of the customer, then the buyer is satisfied or very happy.

According to Zeithaml and Bitner (2000:75) definition of satisfaction were: Response or responses about meeting consumer needs. Satisfaction is an assessment regarding the characteristics or the specialty products or services, or the products themselves, which provide consumer enjoyment level related to the fulfillment of the needs of consumer consumption.

According to Pasuraman, Zeithaml and Berry, [6], suggests that customer satisfaction is a feeling towards one type of customer service that he obtained.

According to Philip Kotler and Kevin Lane Keller cited from the book marketing management say that consumer satisfaction is a feeling happy or upset someone who comes after comparing performance (results) of products that are well thought out on performance expected (2007:177).

Consumer satisfaction is the level of consumer feelings after comparing between what he received and his expectations (Umar, 2005:65). A customer, if satisfied with the value provided by the product or service, it is very likely to become customers in a long time.

According to Philip Kotler (2002:42) "consumer satisfaction is a feeling happy or upset someone who comes from the comparison of the effect on performance (or outcome) of a product and harapan-harapannya". While according to Zulian Yamit (2005:78) "consumer satisfaction is a full evaluation of the results of the evaluation or purchase after comparing what is perceived with his expectations". In the concept of consumer satisfaction, there are two elements that affect IE performance and expectations.

Understanding someone's feelings is the level of Satisfaction after comparing performance or perceived results compared to the expectation (Susanto, 2000).

Definition of Contentment is a value of the juice of a person are satisfying or disappointing that is produced by a process of comparing the existence or appearance of a product of interest against the expected values.

Kotler and Armstrong (1999) States that the customer satisfaction (customer satisfaction) is a level where the estimated performance of the product/service in accordance with the expectations of buyers.

Furthermore, according to Gerson (2001) stated that customer satisfaction is a feeling which is owned by the customer if their needs are real or just the assumption are met or exceeded his expectations.

"Customer satisfaction that is when a product or service meet or exceed the expectations of consumers, usually the customer feel satisfied."

Kotler (2000) stated that if the buyer is satisfied after the buy depending on the look of service compared with expectations or connected which was originally owned by the buyer.

"Satisfaction is a person's feeling of pleasure or disappointment resulting from comparing a product's perceived performance (or outcomes) in relation to his or her expectations."

The concept of social marketing marketing emphasizes the importance of customer satisfaction in supporting the success of the Organization to realize its goals. Simply put, our satisfaction level of a customer against a particular product is the result of a comparison carried out by customers concerned over the level of perceived benefits (perceived) has received after consuming or use the product and the level of benefits expected (expected) before purchase. If the perception of equal to or greater than the expectations, then the customer will be satisfied. Conversely, if expectations are not met then it is dissatisfaction. Experience the satisfaction felt repeatedly raises the level of overall satisfaction akam and makes it easy for customers to draw up a clear future coming ekspetasi. Broadly speaking, customer satisfaction provide two major benefits for the company, namely in the form of customer loyalty and tular gethok (word of mouth) positive.

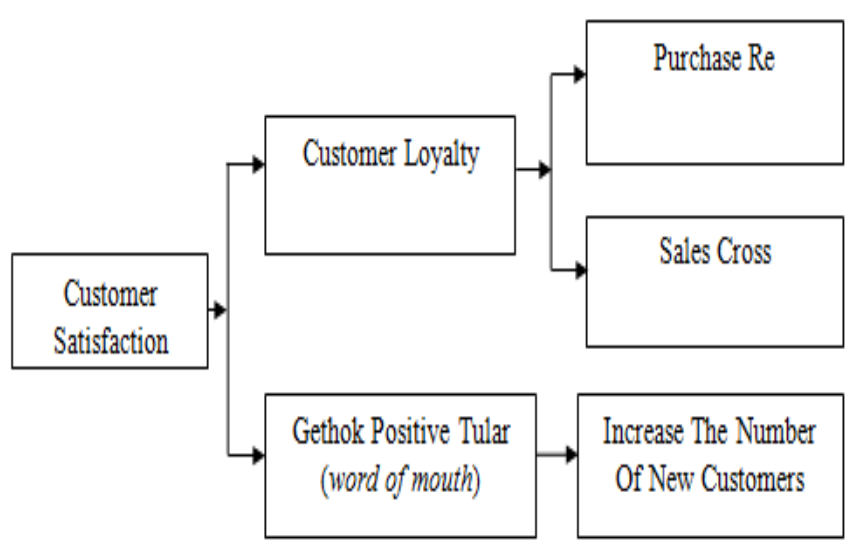

Fig 1:- The Benefits of Customer Satisfaction

In order to create customer satisfaction, product quality organization should offer. The term quality itself contains a wide range of interpretation. Simply put, quality bias refers to a product that is free of defects. However, the defenisi-based manufacturing is less relevant to the service 
sector. Therefore, the understanding of quality is then extended into a "fitness for use" and the conformance to requirements. " Quality reflects all dimensions of product offerings that generate benefits (benefits) for customers. The term value (value) is often used to refer to the relative quality of a product is linked to the price of the product concerned.

According to the American Society For Quality Control (Lupiyoady, 2001), quality is the totality of features and characteristics-characteristics of a product or service in terms of the ability to meet the needs that have been specified or are latent.

Quality of service based on the fulfillment of customer needs and desires as well as the timeliness of delivery to offset customer expectations. In an enterprise quality of service is an important component of the perception of consumers. In the case of services, the quality of service would constitute the dominant element in the evaluation of the consumer.

\section{$>\quad$ The Sense of Service}

While the notion of service according to the General dictionary language Indonesia, WJS Poerwadarminta (1985) is helping provide everything what it takes others as guests or the buyer. In the field of management, some experts in diverse menguraikannnya dioleh from the word "SERVICE", which are as follows:

- Self Awareness Self Esteem \& i.e. instill that sense of self serve is its task and performed it with keeping the dignity of themselves and others who served.

- Empathy \& Enthuasiasm i.e. both empathy and serve customers with full excitement

- Reform i.e., always repair service

- Vision \& Victory i.e. looked into the future and provide a good service to win all parties.

- Initiative providing Impressive \& service with great initiative and memorable parties catered for.

- Care \& Cooperative namely shows attention to consumers and fostering good cooperation

- Empowerment Evaluation i.e. \& self-empowering are directional and always evaluate every action that has been carried out.

From the explanation of each word above, then in the service (service), there are some guidelines that must be met are: awareness, empathy to serve to customers, improve service, always looked to the future, full of initiatives, show concern and always do an evaluation

Based on explanation above in terms of quality, minimum service has five dimensions: Tangible, Reliability, Responsiveness, Assurance and Empathy. His is as follows:

1. Tangible (Physical Appearance), i.e. the existence of apparitions in the form of ancillary facilities, the clerk or the means of communication that accompanies the product.

- Facilities

\section{- Employees}

- Communication Material and equipment

For a service cannot be seen, it cannot be detected and are not palpable, tangible aspect then becomes important as a measure against the Ministry. Customer will use the senses of sight to judge a service quality.

2. Reliability (reliable, the ability to realize the product as promised). Customer satisfaction towards the services companies are also determined by the dimension of reliability, i.e. the dimension that measures the reliability of the company in providing service to its customers. This dimension is particularly important for customers of the various service industries. There are two aspects of this dimension. the first is the ability of the company to provide the service as promised. Second, is how far a company able to provide accurate or no error. In the manufacturing industry is known for the concept of "zero defects", that culture to make the product no defects

- Right time

- Error-free and accurate

- Willingness and honesty of employees

- Fair in service

3. Responsiveness (response) is the desire to help the consumer and provides the speed and accuracy of the service. Customer expectations against the tendency of service almost certainly will change the trend up from time to time. In the language of economy of time is "scarce resources". Therefore time is equal to the money that must be used wisely. That is why customers are not satisfied when the time wasted in useless because she's already lost another opportunity to obtain economic resources. Customers willing to sacrifice or pay for a more expensive service for every time that can be saved.

- Questions answered quickly

- Complaints handled quickly

- To have knowledge and skills

4. Assurance (can be accountable) is the knowledge of the employees in instilling confidence over these products. There are four aspects of this dimension: friendliness, competence, credibility and security. Hospitality is one of the aspects of the quality of service that are most easily measured. One form of concrete is being polite and smile. The aspect of meaning is the competence of each employee of the company must have a good knowledge of a product so don't look dumb when asked the customer. Credibility is the extent to which the company has a good reputation so that customers have the confidence to use the company's products. While security in this case is a customer must have a sense of security when doing transaction. Secure because the company honest transaction.

- Friendly

- Familiar

- Secure

- Reliable

- Being able to communicate 
Zeithmal and Bitner (2003) suggests that satisfaction is a much wider concept than just an assessment of the quality of service, but is also influenced by other factors can dije by explaining the following:

1. Service quality or service, that consumers will be satisfied if they get good service or as expected.

2. The quality of the product, i.e., consumers will be satisfied if their results show that the products they use.

3. Price, i.e., the products have the same quality but the price is relatively cheap will give a higher value to the consumer.

4. Factor in the situation, i.e., circumstances or conditions experienced by consumers.

5. Personal Factors of consumer, namely the characteristics of the consumers that include personal needs.

The factors that influence consumer satisfaction-in determining customer satisfaction there are five factors that must be considered by the company (Lupyoadi, 2001) include: a. product quality, that customers will be satisfied when the results they show that the products they use.

A. The service quality or service, that customer will be satisfied if they get good service or as expected.

$B$. The emotions, that customers will feel proud and get the confidence that other people will be in awe of him when using the product with certain brands that tend to have higher levels of satisfaction. Satisfaction is obtained not because of the quality of the product but the social or self esteem which makes customers feel satisfied towards certain brands.

C. Price, i.e., the products have the same quality but the price is relatively cheap will give a higher value to the customer.

D. Costs, i.e. customers who do not have to pay an extra charge or do not need to waste time to obtain a product or service are likely to be complacent towards the product or service.

According to Dunlap (2004:37), factor - the driving factors of customer satisfaction are as follows:

1. Product quality, customers are satisfied if after buying and using these products turned out to be a good product quality.

2. Prices, for customers who are sensitive, usually cheap prices is a source of satisfaction that important since customers will get value for money.

3. Service quality, satisfaction with the quality of service is usually difficult to emulate. Quality of service is the driver who has many dimensions, one of the most popular is the Servqual.
4. the Emotional Factor, customers will be satisfied (proud) due to the emotional value given by the brand of the product.

5. Costs and convenience, customers will be more satisfied in a relatively easy, convenient and efficient in getting your product or service.

Factors that affect the perception and expectations of the customers according to And within (2005, Nasution: 50) is as follows:

1. Needs and desires relating to things perceived customers as he was trying to make deals with manufacturers/suppliers of products (the company). If at that time the major needs and desires, hopes or expectations of customers will be high, and vice versa.

2. Past experience when consuming the products of the company as well as its competitors.

3. The experience of friends, where they'll tell you the quality of the product to be purchased by that customer. This obviously affects customer perception especially on products perceived high risk.

4. Communication through advertising and marketing also affects customer perception. People in sales and advertising seyogianya not making excessive campaign past level ekspetasi ode to customers.

\section{THE METHOD OF RESEARCH}

Type of quantitative research approach AMOS with the amount of primary Data was collected through interviews, field observations and a question form, while secondary data obtained from multiple instances relating to the object of research .

\section{A. Populations And Samples}

The study population included all residential customers in the city of Makassar both type A (simple home healthy), type B (Middle House), and type C (Mansion). Population is as much as 2500 user includes customers as many as 1200 user type A, type B as much as 840 user, type $\mathrm{C}$ as much as 460 users.

\section{B. Research Instrument}

The instruments used to collect the data needed to test the hypothesis is the questionnaire instrument. A detailed questionnaire designed and tailored to the research objectives. To complement data obtained for authentic also conducted interviews to parties berkompoten in the place of research.

The research results obtained important thing i.e. conceptualization of quality single and comprehensive services within the framework of multi dimensional. Collectively it appears that the results of this study contribute to the disciplines in various fields.

1. Qualitative and empirical Results from this study indicate that the three primary dimensions is composed of 
various subdimensi. Customers base their evaluation of the primary dimension to the assessment of the three interconnected factors. The combination of all of these to form the overall customer perception about the quality of service.

2. Indicate that reliability, responsiveness and empathy service provider holds an important role in providing a good

Being marketed by developer company. quality service. Impilikasi is that which shows how every subdimensi in the evaluation of (realiabel or not responsive or not and so on), while the sub-sub dimensions answered the question that should be realiabel, responsive and empathy.
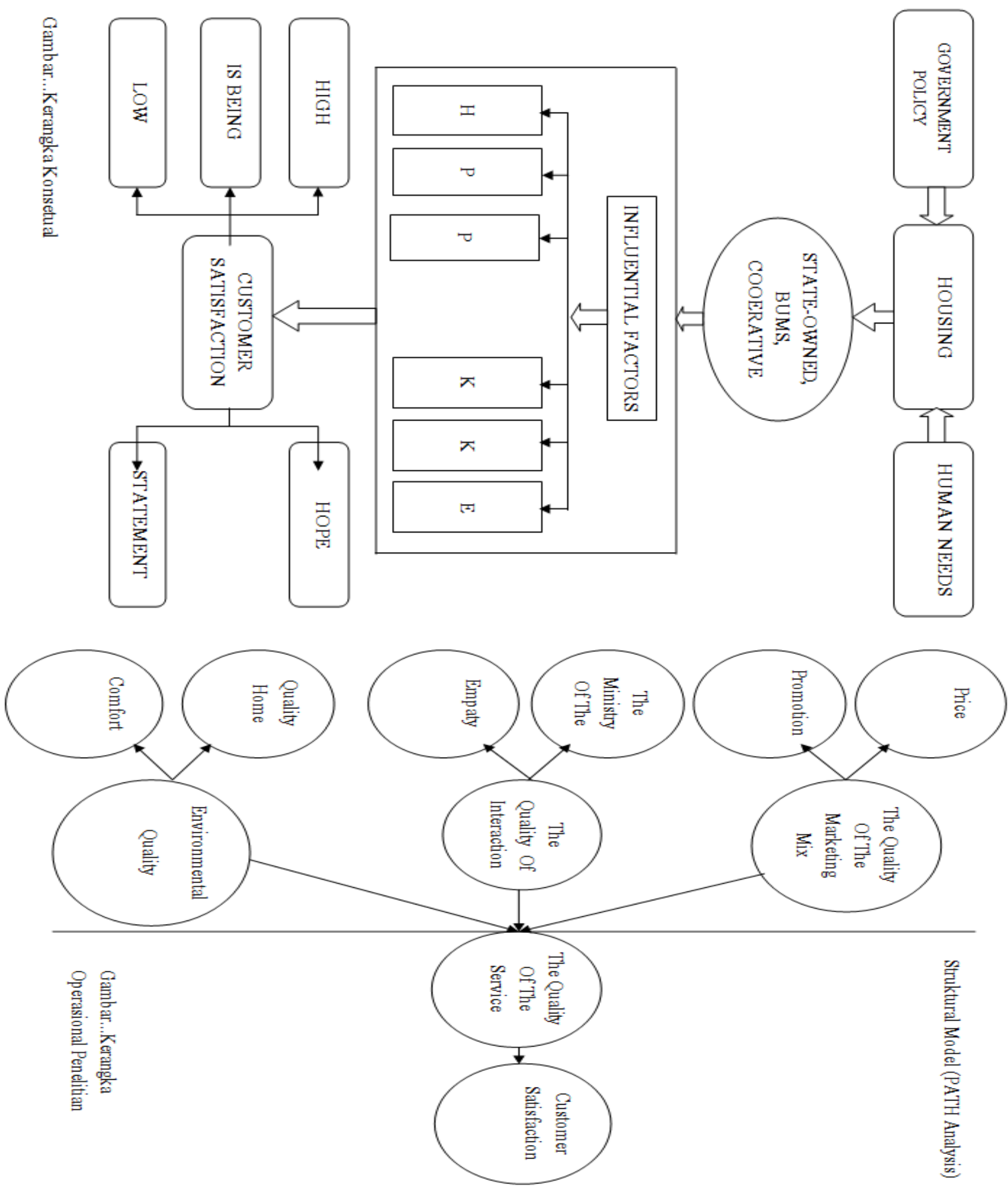


\section{ANALYSIS OF RESEARCH RESULTS}

\section{A. Identification of Respondents}

Based on research data tabulations can put forth the characteristics of the respondents on the basis of gender as it appears that the number of male respondents dominate the overall respondents in this research. The number of male respondents as much as 94 people $(75.20 \%)$ respondents are female-sex as many as 31 people $(24.80 \%)$

Data about the respondent's answers against the statement related to the perceptions of the respondents to the quality of the purchased home retrieved from 125 respondents, quantitatively showed that the lowest total score is 4 and the highest total score is 19 . Based on the results of the processing of data in the above descriptive statistics, can generally be dinyatakab that most or 57 people $(45.60 \%)$ respondents felt enough satisfaction to quality home that she had purchased. The results of this analysis showed that satisfaction with the quality of the House is purchased very related to building construction. the House is purchased, the physical condition of the building of the House is purchased, the building materials used, as well as in design. model, and the shape of the House is purchased.

\section{B. The Results of The AnalisisStructural Equation Models (SEM) Early Stages \\ The model is said to be good when the model} development hypothesis theoretically supported by empirical data. SEM test results for the major hypotheses are evaluated based on goodness of fit indices. Significance levels (p) of 0000, suggests that the zero hypothesis which States there is no difference between the sample covariance matrix with a matrix of covariance populations being estimated is rejected. Thus there is a difference between the sample covariance matrix with matrix kovanians populations being estimated so that the model is not yet feasible to use.

\section{The Results of The Analysis of Structural Equation Models (SEM) The Final Stage}

SEM analysis of results on the final stage. Significant levels (p) by 0213 , suggests that the zero hypothesis which States there is no difference between the sample covariance matrix with a matrix of covariance populations being estimated is acceptable. Thus there is no difference between the sample covariance matrix with a matrix of covariance which popuIas being estimated so that the model can be used while the index-jndeks Iainnya (CMIN/DF TLI, CFI, and RMSEA) also indicates the level of acceptance against the model know how the marketing mix partially residential customer satisfaction toward Makassar city.

Based on the results of the analysis of the SEM as shown that the value of the coefficient indicates the value of direct (posisitif) with the hypothesized value and $\mathrm{p}$-value shows the effect was not significant. With the more minor hypothesis (H-3) stating posisitif and influential physical environment significantly to customer satisfaction declined. The results of this test does not support the research results and Brady Cronin (2001) that proves there are three factors that affect the perceived quality of the physical environment that is the dimension of the ambient condition (the condition of the room), the design of the facility, and social factors, Sharma and Stafford (2000).

\section{The Influence of The Quality of The House Towards Customer Satisfaction.}

Based on the results of the analysis of SEM showed that the value of the coefficient of pam 0251 and value $p$ value of 0163 . Path coefficient value is unidirectional (positive) and the hypothesized value while p-value shows the influence of insignificant so minor hypothesis (H-3a) stating the quality home in a positive and significant effect against customer satisfaction is rejected.

Analysis results can be explained that its residential customers would perceive the satisfaction he felt based on their evaluation of the quality of the House that she had purchased. This situation shows that most developers of housing, especially in Makassar city has not been able to provide an adequate level of satisfaction to customers especially in terms of the quality of a home being marketed or it can also be said that residential customers in the city of Makassar has not been satisfied with the quality of the House being marketed by developer company.

SEM analysis of results shows the value of path coefficient - o 165 and P-value value of 0334 . The value of path coefficient value koefisen shows and p-value shows the influence is not significant. The results of this study do not support the research results Sharma and (2000).

In principle any type/model home must meet the standards in four aspects: (1) health aspects, (2) aspects of ke3sehatan, (3) comfort, affordability and (4). Parts of the House that affect family health must be well prepared, can thus be explained that the main focus is the convenience factor that needs to be taken care of by the company the developer if you want to improve customer satisfaction customers or in other words residential customers in the city of Makassar not satisfied against the convenience factor created by the company penggembang in terms of layout/position of houses, public facilities, social falitas, and security conditions in the complex

\section{E. Satisfaction of The Quality of The Interaction Towards Customer Satisfaction.}

Based on the results of the analysis of SEM showed that the value of 0.185 path coefficients and coefficients of $\mathrm{p}$-value of 0.098 . The value of the coefficient indicating the same direction (positive) and the dihipotesisikan and the value of the $p$-value shows the influence of the sinifikan not so hipotesisi and significant major $(\mathrm{H}-4)$ stating the quality called the effect of positive and significantly to customer satisfaction is rejected. The results of this study do not support the results of the research Parasraman et. Al (1988) mention that the company should be able to provide appropriate services promises to accurately and reliably.

\section{F. The Influence of Service to Customer Satisfaction}

Conceptually a positive and significant effect of service towards customer satisfaction. Based on the results of the analysis of SEM, coefficients of path-0, 020. And the value of the coefficients of a p-value of 0.828 . This means that the value of the coefficient indicates the path in the 
opposite direction (negative) with that hypothesized and pvalue shows the influence of insignificant so minor hypothesis (H-4a) stating that the Ministry take effect posisitf and significantly to customer satisfaction is rejected. The results of this study do not support the study results et.al Parasuraman (1988).

\section{G. The Influence of Empathy Toward Customer Satisfaction}

Theoretically the positive influence of empathy and sinifikan towards customer satisfaction. Marketers who have empathy are the marketers who are able to see every sales situation from the customer's perspective with the aim to help the customer achieve success.

\section{H. The results of the research findings}

Of the quality housing services consisting of the quality of the marketing mix, the quality of the interaction, and the quality of the physical environment have an influence on the satisfaction of residential customers can be expressedas the research findings the following;

The marketing mix consists of price and promotion of positive and significant influence towards customer satisfaction. This implicates that pricing and promotion system traveled by corporate marketers housing should get serious attention for the quality of the service housing is very related to the perception of customers against price and promotion strategies taken by the company.

The physical environment consists of the comfort and quality of the House had a positive influence but not significant toward the satisfaction of residential customers. This implies that for an institution's business especially in the field of housing services should be able to pay attention to factors that can make customers feel comfortable qualities of interaction that consists of service and empathy have an influence positive but not significant toward the satisfaction of residential customers. This implies that the service (timeliness, on-site service, consistency, service and interpersonal relationships to be built) and empathy (attention given, the ability resolve complaints, problems and needs of the customer and a partnership company) for an agency business must get attention because customers would rate the quality of service based on quality of service and empathy that was provided by the company.

\section{CONCLUSION}

This study seeks to test hypotheses related to the influence of the quality of services towards customer satisfaction, influence marketing mix towards customer satisfaction, the influence of the physical environment towards customer satisfaction, and influence the quality of the interaction towards customer satisfaction with research using a sample of 125 people in Makassar city residential customers. The model used is the analysis of Structural Equation Models (SEM). Based on the results of the research, it can be summed up as follows

1. These results indicate that simultaneously the marketing mix, the physical environment, and the quality of interaction can enhance the satisfaction of residential customers.

2. Marketing mix effect positively significantly to customer satisfaction. Partially be explained that:

Price positive and significant effect towards customer satisfaction. This means that home pricing policy carried out by the company's marketers in the city of Makassar responded positively olehpelanggan and ultimately affect the perceived satisfaction of customers. Thus the company should be able to guarantee the similarity between the price offered by the fact House prices are bought, giving gifts, bonuses, and a discounted price, guarantee the similarities between house prices with quality homes that can be felt customers, and pay attention to pricing strategies to sell.

The promotion of a positive and significant effect towards customer satisfaction. This means that the promotional strategy that run corporate marketers responded positively and ultimately increase customer satisfaction. This situation illustrates that the promotion system that is run by a housing developer in the city of Makassar should pay attention to media promotion that is used, ensuring consistency of information submitted through media promotion, promotional intensity and the quality of the information submitted, the positive effect of physical environment and insignificant towards customer satisfaction. Partially be explained that:

Quality House of influential positive and insignificant towards customer satisfaction. This means that the quality of a home being marketed by marketing companies in the city of Makassar less responded positively by customers so that the improved quality of the House does not have an effect on customer satisfaction. These results indicate that if the company wants to acquire housing marketers in a positive response from customers should pay attention to the location/position home, completeness, public facilities and social facilities, and ensure conditions of security in housing complex .

The convenience of no effect negative and insignificant towards customer satisfaction. This means that the comforts of home, which is marketed by the company's marketing is not responded positively by customers so that the quality of the construction of the building, which include the physical condition of the building materials used, as well as the design, the model and the form of the House is not influential to increased customer satisfaction.

The quality of the interaction was not significant and positive effect toward customer satisfaction. Partially be explained that:

The influential Ministry of the negative and insignificant towards customer satisfaction. This indicates that the services provided by the marketing company housing in the city of Makassar not responded positively by customers so that the services provided have no effect against the increase in customer satisfaction. For that, so that customer satisfaction is increased then the company should pay attention to the timeliness of service, on-site service in 
the Office of marketing, consistent in providing services, and maintain interpersonal relationships between officers of the Ministry with customer.

The positive effect of empathy and insignificant towards customer satisfaction. This suggests that empathy given by marketing firm less responded positively by customers so there is no effect on customer satisfaction. For that the company paid close attention to the customer, being able to address the complaints and problems, customers were able to understand the needs of customers, and has a high commitment towards customer satisfaction.

The empirical research provides evidence that customers are basically shape the perception of the quality of the services on the basis of the evaluation that he did against the three primary dimensions of marketing mix namely, physical environment, and the quality of the interaction. The results of the qualitative and empirical research indicates that these three dimesi this interconnected and form an overall customer perception of the quality of housing services.

There are two variables which were positive response by residential customers in the city of Makassar, i.e. the physical environment and the quality of the interaction that implies no residential customer satisfaction increases. This reflects the high expectations of the customers will be the company's attention on the quality and comfort of a home built that was created in the housing complex. Similarly on the conditions of service and empathy of the company, therefore it is recommended that enterprise developers to focus on the strategy of improving the quality of the physical environment and the comfort of a residential complex without forgetting factor service factor and empathy.

\section{DAFTAR PUSTAKA}

[1]. Arbuckle, JL. And Wonthke, W., 1999, AMOS 4.0 User's Guide.Chicago, Smallwaters Corporation.

[2]. Alex Nitisemito. 1989. Marketing.Cet. V. Ghalia Indonesia, Jakarta.

[3]. Arikunto dan Suharsimi, 1993,Prosedur Penelitian, Suatu Pendekatan Praktek, Cetakan Sembilan Penerbit Rineka Cipta, Jakarta.

[4]. Arsyad, L 1991.Ekonomi Manajerial, Ekonomi Mikro Terapan Untuk Manajemen dan Bisnis BPFE-UGM, Yogyakarta.

[5]. Athanassopoulos, Antreas D., 2000, Customer Satisfaction Cues to Support Market Segmentation and Explain Switching Behavior. Journal of Bussiness Research Vol. 47 : 191 - 207.

[6]. Ballantyne, D. (2000), "Internal Relationship Marketing: A strategy for knowledge Renewal", The International Journal of Bank Marketing, Vol. 18 No.6

[7]. Basu Swasta dan Irawan. 1981. Manajemen Pemasaran Modern. Liberty, Yogyakarta.

[8]. Brady, Michael K and J. Joseph Cronin, 2001,Some Thoughts on Conceptualizing Perceived Service Quality: A Hierarchical Approach, Journal of Marketing Vol. 65, 34-49.
[9]. Bennet, Peter, 1988, Marketing, The United States of America: Mc Graw Hill, Inc.

[10]. Berry, L.L. and Parasuraman, A. (1991),MarketingService: Competing through Quality, The Free Press, p. 152.

[11]. Cravens, David W, 1987, Strategic Marketing, Second Edition, Rich-and D. Irwin.Inc.

[12]. Cronin Jr., J. Joseph,Brady Michael k and Hul G. Thomas m., 2000,Assessing the Effect of Qualioty, Value and Customer Satisfaction and Behavior intention in Service Enveroments. Journal of Retailing Vol. 76 (2) pp. 193 - 218.

[13]. Dabhokar, Prathiba A., Dayle I., Thorpe and Joseph O. Rentz, 1996,A Measure of Service Quality for Retail Stores: Scale Development and Validation. Journal of Academy of Marketing Scince 24 (1): 3-16.

[14]. Dajan, ANto. 1986. Pengantar Metode Statistik. Penerbit LP3ES, Jakarta.

[15]. Day, G. S.and Fashey, L. (1988).Valuing Market Strategis, Journal of Marketing, 52, 45-57.

[16]. Day, G. S. and Wensley, R. (1988)Assesing Advantage: A. Framework for diagnosing Competitive Superioority, Journal of Marketing, 52, 1-20.

[17]. Dixon, D,F and Blois, K.J (1983), "Some Limitations of the 4Ps as a Paradygm for Marketing". Marketing Education Groupo anualo Conference, Cranfield Institute of Technoglogy, UK.

[18]. Foss, N.J. (1997), "Resources Firms and Strategis A reader in the resooource based prespective", Oxford University Press, UK.

[19]. Goleman, Daniel, 1995,Emotional Intelegence: Why it Can Matter More Than IQ, Bantam Books, New York.

[20]. Groos, Babara L., et.al., 1991, Why We Buy: A Theory of Consumtion Values, Journal of Busionnes Research, Elsevier Publisher.

[21]. Hadi Sutrisno, 1990,Statistik, Jilid 2, Andi Offset, Yogyakarta.

[22]. Hiam, Alexander, Charles D. Schewe, 1994,The Portable MBA Pemasaran, ALih Bahsa: Ir. Agus Maulana, Binarupa Aksara, Jakarta.

[23]. Hudaya, Miya Rachmil, 1994,Pengaruh Strategi Bauran Pemasaran Terhadap Kepuasan Konsumen Pada Kentucky Fried Chicken Bandung, Tesis Program Magister Manajemen, Universitas Padjajaran Bandung.

[24]. Kartajaya, Hermawan, 1997,Marketing Plus 2000: Siasat memenangkan Persaingan Global, Gramedia Pusataka Utama, Jakarta.

[25]. Kartajaya, Hermawan, 2003,Marketing in Venus: The 18 Guiding Principles of Marketing in Venous, Pt. Gramedia Pustaka Utama, Jakarta.

[26]. Komaruddin, 1996,Menelususri Pembangunan Perumahan dan Permukiman, Yayasan Realestat Indonesia, Jakarta.

[27]. Kotler, Philip. 1980,Marketing Management: Analisis Planning ang Control. Fovth Edition, New Dehli, Practice Hall of India.

[28]. Lovelock, Crishtoper H., 1991.Service Marketing: Second Edition, Prentice-Hall International Edition.

[29]. LPPM Jakarta, 1997.Teknik Menjual Persuasif Produk Properti, Makalah DPD REI Provinsi Sulawesua Selatan, Ujung Pandang. 
[30]. Marketing Science Institute (2000), Research Priorities 2000- 2002, MSI, Cambridge, Massachusethhs.

[31]. Nazir, Moh., 1985, Metode Penelitian, Ghaliah Indonesia, Jakarta.

[32]. Oliver, R.L and W.S. DeSarbo, 1988, Response Determinants is Satifaction Judgements, Journal Od Consumer Research, Vol. 14.

[33]. Pawitra D. Converse et. Al. 1968. Kepuasan Pelnggan Sebagai Keunggulan Daya Saing: Konsep, Pengukuran, dan Implikasi Strateis, Jurnal Manajemen Prasetiya Mulya, Volume I No1.

[34]. Prayitmo, S. 1993.Apakah Iklan Anda Efektik ?: Manajemen dan Usahawan Indoneisa, No. 8 Vol. XXII.

[35]. Rangkuti, Freddy, 2003,Measuring Cotumer Satisfaction: Teknik Mengukur dan Strategi Meningkatkan Kepuasan Pelanggan, PT. Gramedia Pustaka utama, Jakarta.

[36]. Sarmoto. 1983.Dasar-Dasar Organisasi dan Manajemen, Edisi Revisi, Cet. IV. Ghalia Indonesia Jakarta.

[37]. Stanton, William J., 1984,Prinsip Pemasaran, Diterjemahkan Oleh Yohannes Lamarto, Erlangga, Jakarta

[38]. Subagyo, Slamet dan Afandy, Harry, 1996,Perumahan Ideal Kawasan Realestate, DPD REI Jawa Tengah.

[39]. Sugiyono, 2000.Statiska Untuk Penelitian, Alfabeta, Jakarta.

[40]. Surakhmad, Winarno, 1982,Pengantar Penelitian Ilmiah: Dasar, Metode, Teknik, Tarsito, Bandung.

[41]. Tjiptono, Fandy, 1995,Strategi Pemasaran, Andi Offset, Yogyakarta.

[42]. Winardi, 1980.Azas-Azas Marketing.Cet. III. Alumni Bandung.

[43]. Zeithaml, Valarie A. , 10996,Service Quality, Profitability, and the Economic Worth of Customers: What we Know and What we need to learn.Journal of The Academy of Marketing Sciences, 28 (1): 67-85. 